\title{
PEMODELAN REGRESI LATEN PADA EFEK PLASEBO MEMAKAI METODE MAXIMUM LIKELIHOOD
}

\author{
Diana Purwandari ${ }^{1}$ \\ ${ }^{1}$ Universitas Muhammadiyah Tasikmalaya \\ diana.math44@gmail.com ${ }^{1}$
}

\begin{abstract}
Regression modeling can model the form of the relationship, for example the response variable to one or more predictor variables. Modeling will be more complicated if we use unmonitored latent predictors. Latent regression modeling has a major role in modeling latent variables, for example the placebo effect in depression recovery. Latent regression modeling on the placebo effect was estimated using the beta distribution. While the model parameters are estimated to use the maximum likelihood method. The results of the study are in the form of a latent regression equation that explains the placebo effect on depression recovery.

Keywords: Latent Regression, Placebo Effect, Depression, Maximum likelihood method.
\end{abstract}

\begin{abstract}
Abstrak
Pemodelan regresi dapat memodelkan bentuk hubungan misalnya variabel respons terhadap satu atau beberapa variabel prediktor. Pemodelan akan lebih rumit apabila menggunakan prediktor laten yang tidak terpantau. Pemodelan regresi laten memiliki peran utama dalam memodelkan variabel laten, contohnya efek plasebo dalam pemulihan depresi. Pemodelkan regresi laten pada efek plasebo diduga menggunakan model regresi laten multivariat. Sedangkan parameter model diduga memakai metode maximum likelihood. Hasil penelitian berupa persamaan regresi laten yang menerangkan efek plasebo dalam pemulihan depresi.
\end{abstract}

Kata Kunci: Regresi Laten, Efek Plasebo, Depresi, Metode maximum likelihood.

Received: November 05, 2020 / Accepted: November 30, 2020 / Published Online: December 31, 2020 


\section{PENDAHULUAN}

Pada Pemodelan regresi dipelajari bagaimana variabel-variabel tersebut berhubungan dan dapat ditulis dalam bentuk persamaan matematika. Pemodelan akan lebih rumit apabila menggunakan prediktor laten, yaitu prediktor yang tidak terpantau (unobserved predictors). Contohnya nilai kuantitas pada prediktor laten didapat meenggunakan prosedur estimasi (perkiraan). Pemodelan regresi dengan prediktor laten (tidak terpantau) disebut regresi laten. Efek plasebo merupakan salah satu masalah yang dapat diatasi dengan model regresi laten.

Plasebo merupakan istilah medis dalam farmasi untuk obat tanpa bahan kimia yang biasanya hanya berisi cairan garam saja atau gula saja. Efek plasebo merupakan efek pengaruh yang dapat menyembuhkan orang dengan meyakini terhadap sejenis obat tertentu. Salah satu kelebihan efek plasebo adalah dapat digunakan dalam farmasi terutama untuk pengobatan dan pemulihan. Penyakit yang dapat berubah secara kontinu dan tidak terpantau untuk jangka waktu yang lama serta dapat diobati dan dipulihkan dengan efek plasebo, yaitu depresi.

\section{METODE PENELITIAN}

Penelitian ini disusun menggunakan studi literatur dengan mencari berbagai informasi mengenai regresi laten. Data yang diperoleh menggunakan data sekunder terhadap pasien depresi. Sumber data pasien depresi diperoleh dari nara sumber Tarpey dan Petkova (2010) yang meneliti pasien depresi rawat jalan. Penelitian ini mengamati pasien perempuan dan laki-laki yang berusia 18-65 tahun. Jumlah responden yang terkena depresi pada penelitian ini sebanyak 393 orang.

Metode yang digunakan untuk menduga model regresi laten, yaitu metode maximum lilelihood. Tujuan utama dari penelitian ini adalah membuat model regresi laten pada efek plasebo, parameter model regresi laten memakai metode maximum likelihood, dan aplikasi model regresi laten dengan data pengobatan dan pemulihan depresi.

Tahapan analisis data dan pemrograman yang dilaksanakan pada penelitian ini, yaitu: 
1. Membuat model regresi dengan inisialisasi setiap parameter.

2. Melakukan estimasi (menduga) parameter laten menggunakan metode maximum likelihood.

3. Melakukan aplikasi model regresi laten dengan data pengobatan dan pemulihan depresi pada pemrograman menggunakan software $R$ 2.13.1.

\section{HASIL DAN PEMBAHASAN}

Analisis statistik yang dapat dipakai untuk menganalisis data adalah analisis multivariat dengan data yang dipakai lebih dari satu variabel prediktor dan banyak variabel respons, sehingga model regresi laten pada efek plasebo, yaitu:

$$
\boldsymbol{y}=\boldsymbol{\beta}_{0}+\boldsymbol{\beta}_{1} x+\varepsilon
$$

dengan:

$\boldsymbol{\beta}_{\mathbf{0}}:$ parameter regresi

$\boldsymbol{\beta}_{1}$ : parameter regresi

$\boldsymbol{y}$ : variabel respons

$\boldsymbol{x}$ : variabel prediktor

$\varepsilon$ : error

Apabila prediktor laten $x$ tidak terpantau maka persamaan (1) disebut model regresi laten.

Metode yang tepat digunakan untuk masalah depresi adalah metode maximum likelihood. Metode maximum likelihood merupakan metode yang terbaik untuk mendapatkan sebuah parameter tunggal, dengan memisalkan $X_{1}, X_{2}, \ldots, X_{n}$ masingmasing variabel acak saling bebas dengan sebaran yang mempunyai FKP (Fungsi Kepekatan Peluang) berupa $f(x ; \theta)$ dengan $0 \leq \theta \leq 1, \theta \in \Omega$ dan $\Omega$ merupakan ruang contoh. FKP bersama dari $X_{1}, X_{2}, \ldots, X_{n}$ adalah $L\left(\theta \mid X_{1}, X_{2}, \ldots, X_{n}\right)=$ $f\left(X_{1} \mid \theta\right) f\left(X_{2} \mid \theta\right) \ldots f\left(X_{n} \mid \theta\right)$ yang biasa disebut sebagai fungsi kemungkinan.

Apabila mencari fungsi sederhana dari $x_{1}, x_{2}, \ldots, x_{\mathrm{n}}$ yaitu $\left(x_{1}, x_{2}, \ldots, x_{\mathrm{n}}\right)$ sehingga $\theta=u\left(x_{1}, x_{2}, \ldots, x_{\mathrm{n}}\right)$ untuk menciptakan fungsi kemungkinan $\mathrm{L}$ maksimum untuk semua $\theta \epsilon \Omega$. Statistik $u\left(x_{1}, x_{2}, \ldots, x_{\mathrm{n}}\right)$ disebut penduga kemungkinan maksimum dari $\theta$ yang 
disimbolkan dengan $\hat{\theta}=u\left(X_{1}, X_{2}, \ldots, X_{\mathrm{n}}\right)$. Karena data berupa parameter laten maka untuk menduga parameter dengan memakai metode maximum likelihood tidak bisa secara langsung. Sehingga untuk menduga parameter laten dapat melakukan pemrograman menggunakan software $R$ 2.13.1.

Aplikasi model regresi laten pada efek plasebo dapat menggunakan software $R$ 2.13.1. Pendugaan parameter dengan variabel kontinu dengan distribusi peluang dilihat dari perubahan respon pasien yang terkena depresi dimulai dari awal sampai akhir minggu pertama memperlihatkan kurva kerapatan non-parametrik bagi variabel respons $y$ yang dapat dilihat pada Gambar 1 .

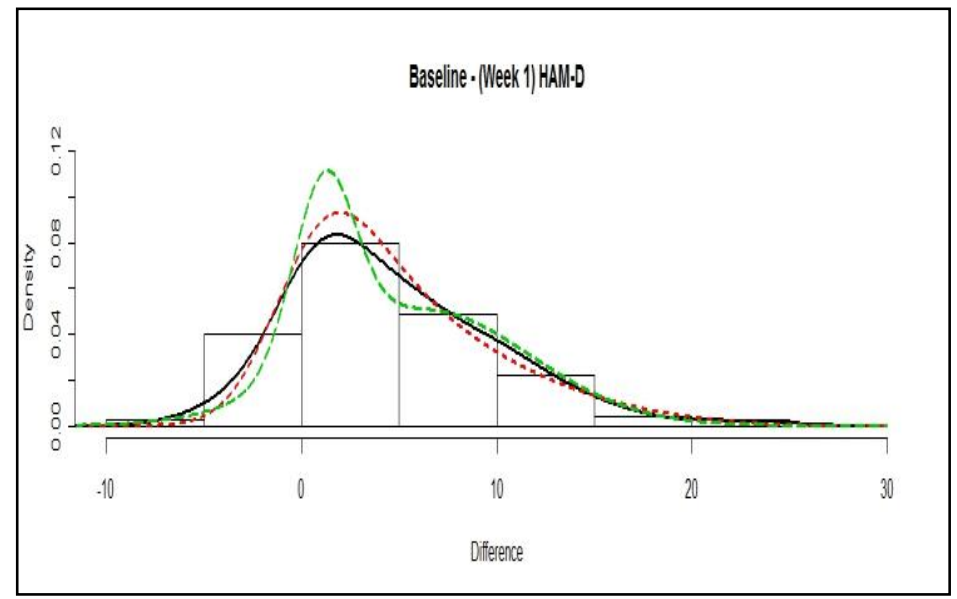

Gambar 1. Histogram Penurunan Depresi Rawat Jalan

Pada Gambar 1 yang memperlihatkan Histogram Penurunan Depresi Rawat Jalan menghasilkan perubahan positif yang signifikan. Untuk mengukur perubahan tingkat gejala yang terkena depresi dapat diukur pada skala Hamilton Depression Rating (HAMD). Terlihat jelas pada Gambar 1 bahwa kurva kerapatan non-parametik menunjukkan distribusi miring (condong). Semua pasien yang terkena depresi memberikan perubahan positif dengan derajat peningkatan yang relatif baik. Perkiraan kepadatan non-parametrik ditunjukkan dengan kurva solid warna hitam, perkiraan kepadatan regresi ditujukkan dengan kurva putus-putus warna merah, perkiraan kepadatan campuran terbatas ditujukkan dengan kurva putus-putus warna hijau.

Untuk mengestimasi parameter model regresi laten maka dapat menggunakan software $R$ 2.13.1, dengan hasil estimasi parameter regresi laten, yaitu 


$$
\hat{y}=26.604 x-0.279 \text {. }
$$

Selanjutnya mencari nilai determinasi $\left(R^{2}\right)$ dengan uji Sharpio-Wilks untuk normalitas yang menghasilkan sebesar 0.95. Koefisien Determinasi yang sangat tinggi ini menunjukkan kesesuaian pendekatan model regresi laten cocok untuk pemantauan efek plasebo pada pasien yang terkena depresi.

\section{KESIMPULAN}

Pemodelan regresi laten pada efek plasebo dapat merujuk pada persamaan regresi linier dengan prediktor laten $x$ tidak terpantau menggunakan analisis multivariat. Metode yang digunakan untuk menduga atau mengestimasi parameter regresi dengan prediktor laten, yaitu dengan metode maximum likelihood. Persamaan regresi laten pada efek plasebo untuk penelitian terhadap pasien depresi adalah

$$
\hat{y}=26.604 x-0.279 \text {. }
$$

Hasil pendugaan parameter regresi pada kasus pasien depresi memberikan perubahan positif dengan derajat peningkatan yang relatif baik. Hasil ini dapat dilihat dari koefisien gradien perubahan positif dengan perubahan suasana hati senang yang bertambah besar. Pengujian untuk normalitas kesesuaian pendugaan menghasilkan Nilai determinasi $\left(R^{2}\right)$ sebesar 0.99, artinya pendekatan model regresi laten ini menunjukkan kesesuaian yang sangat tinggi pada efek plasebo untuk pasien yang terkena depresi depresi sebesar $99 \%$.

\section{DAFTAR PUSTAKA}

Dempster AP, Laird NM, Rubin D. 1997. Maximum Likelihood from Incomplete Data Via the EM Algorithm. Journal of the Royal Statistical Society: Vol. B, No. 39, hlm. 1-38.

Hogg RV, Craig AT, McKean JW. 2005. Introduction to Mathematical Statistics. Ed Ke-6. New Jersey : Prentice Hall, Inc.

McLachlan GJ, Krishnan T. 2008. The EM Algorithm and Extension. Ed Ke-2. New York : Wiley. 
Jurnal Lebesgue : Jurnal Ilmiah Pendidikan Matematika, Matematika dan Statistika

Diana Purwandari

Volume 1, No. 3, Desember 2020 hal.193-198

DOI Artikel : 10.46306/lb.v1i3.40

Rencher AC, Schaalje GB. 2008. Linear Models in Statistics. Ed Ke-2. New Jersey : John Wiley and Sons, Inc.

Ross SM. 2007. Introduction to Probability Models. Ed Ke-9. Calivornia : Elsevier, Inc.

Tarpey T, Petkova E. 2010. Latent Regression Analysis. Statistical Modelling: Vol. 10, No. 2, hlm 133-158. 